\title{
Angiopoietin-like protein 7 mediates TNF- $\alpha$-induced adhesion and oxidative stress in human umbilical vein epithelial cells
}

\author{
Jiong $\mathrm{Li}^{1,2, *}$, Tianxiang Liang ${ }^{2, *}$, Yanzheng $\mathrm{Wang}^{2}$, Yirong $\mathrm{Gan}^{2}$, Zongke $\mathrm{Kou}^{2}$, Yunlong \\ Zhang ${ }^{2}$, Rui $\mathrm{Mao}^{2}$ and Dingxiong $\mathrm{Xie}^{2,3}$ \\ ${ }^{1}$ Key Laboratory of Preclinical Study for New Drugs of Gansu Province, School of Basic Medical Sciences, Lanzhou University, \\ Lanzhou 730000, China \\ ${ }^{2}$ Gansu Cardiovascular Institute, Lanzhou 730050, China \\ ${ }^{3}$ Lanzhou University Second Hospital, Lanzhou 730030, China
}

\begin{abstract}
Tumor necrosis factor- $\alpha$ (TNF- $\alpha$ ) promotes monocyte adhesion to endothelium and accumulation of endothelium will lead to atherosclerosis. The present study explored angiopoietin-like protein (Angptl7) as a potential target in the process of atherosclerosis, and its role in the adhesion and oxidative stress induced by TNF- $\alpha$ in human umbilical vein epithelial cells (HUVEC). The initiation of atherosclerosis is endothelial injury. Angptl7 was dramatically increased in TNF- $\alpha$-induced HUVEC compared to the control cells. After Angptl7 effectively knocked-down in TNF- $\alpha$-induced HUVEC, the levels of reactive oxygen species (ROS), interleukin (IL)-1 $\beta$, IL-6 and cyclooxygenase-2 (Cox-2) were prominently decreased, whereas the levels of nitric oxide (NO) and endothelia nitric oxide synthase (eNOS) were increased. Inhibition of Angptl7 significantly reversed TNF- $\alpha$-induced cell adhesion in HUVEC. Finally, downregulation of Angptl7 significantly reduced the expression of nuclear factor- $\mathrm{\kappa B}(\mathrm{NF}-\mathrm{\kappa B})$ and enhanced the levels of nuclear factor erythroid 2-related factor 2 (Nrf-2) and heme oxygenase-1 (HO-1) in TNF- $\alpha$-treated HUVEC. Angptl7 conducted TNF- $\alpha-$ induced oxidative stress and cell adhesion in HUVEC. Therefore, Angptl7 might participate in the development of endothelial injury and further atherosclerosis. This might give us a new insight for investigation of procession of atherosclerosis.
\end{abstract}

Key words: Angiopoietin-like protein 7 - Atherosclerosis - Cell adhesion - Oxidative stress Inflammation

\section{Introduction}

Atherosclerosis is the most common cause of cardiovascular disease. Preclinical assessment of changes in vascular endothelial cells plays a pivotal role in improving cardiovascular risk (Onat et al. 2011). Endothelial cell dysfunction exists in the injurious lesion of arterial blood vessels, which is an early marker of atherosclerotic injury (Virmani et al. 2000; Bar et al. 2019). Vascular endothelium is a layer of monocytes on the inner walls of

\footnotetext{
* These authors have the similar contribution to this investigation. Correspondence to: Dingxiong Xie, Gansu Cardiovascular Institute, No. 1 of Wujiayuan West Street, Qilihe District, Lanzhou 720050, China

E-mail: xiedingxiong45@126.com
}

blood vessels, regulating vascular wall function via autocrine and paracrine system. Human vascular endothelial dysfunction is caused by oxidative stress and promoted inflammatory signaling in endothelial cells (Migrino et al. 2017). Importantly, vascular inflammation is a main initial effect to induce atherosclerosis that is a complex vascular injury. The vascular plaques are formed by the interaction of plasma lipids with vascular wall and immune cells (Forstermann et al. 2017). In addition, tumor necrosis factor- $\alpha$ (TNF- $\alpha$ ) promotes monocyte adhesion to the endothelium (Ende et al. 2014), and stimulates expression of vascular cell adhesion molecule-1 (VCAM-1) and intercellular adhesion molecule-1 (ICAM-1) (Li et al. 2019). The aggregation of endothelial cells to monocytes contributes to the inflammatory response and the development of atherogenesis (Napoleone et al. 1997). 
Elevation of reactive oxygen species (ROS), inflammation, high levels of free fatty acids (FFAs) and reduction of NO are classical hallmarks of endothelial dysfunction.

A variety of studies indicated that transcription factor, nuclear factor- $\kappa \mathrm{B}(\mathrm{NF}-\kappa \mathrm{B})$, participates in the induction of adhesion molecules (VCAM-1, ICAM-1) in inflammatory experiments (Bhaskar et al. 2016). TNF- $\alpha$ induces ROS via endothelial mitochondria and activated NF- $\kappa$ B and secretion of IL-6 (Schulze-Osthoff et al. 1993). NO is formed by metabolization of L-arginine via endothelial isoform of nitric oxide synthase (eNOS) (Ye et al. 2019). Generation of ROS and reduction of NO in endothelial cell are key events in atherosclerosis (Forstermann et al. 2017). Activation of nuclear factor erythroid 2-related factor 2 (Nrf-2) suppresses oxidative stress in vascular endothelial cells (Zhu et al. 2019) by binding to antioxidant response element (ARE), including quinone oxido-reductase 1 (NQO1) (Yang et al. 2019), heme oxygenase-1 (HO-1) (Kapoor et al. 2019), and the expression of toll-like receptor 4 (TLR4) (Shan et al. 2019).

Angiopoietin-like (Angptls) proteins have been identified to include a coiled-coil domain and a fibrinogen-like domain which is similar to angiopoietins. Up to now, 7 proteins have been identified as members of the Angptls family. As a secreted glycoprotein, Angiopoietin-like protein 7 (Angptl7) could reduce tumor growth and aberrant blood vessel formation (Parri et al. 2014). Recent research indicated that Angptl7 contributes to AngII-induced proliferation, inflammation and apoptosis in vascular smooth muscle cells (Zhao et al. 2019). In current study, we employed cultured human endothelial cells to explore the roles of Angptl7 in TNF- $\alpha$ induced adhesion and oxidative stress, and to elucidate the further mechanism.

\section{Materials and Methods}

\section{Cell culture}

Human umbilical vein endothelial cells (HUVEC) were obtained from China Center for Type Culture Collection (Wuhan, China) and cultured in minimum essential medium (MEM Eagles with Earle's Balanced Salts; Gibco, ThermoFisher Scientific, USA) supplemented with 10\% fetal bovine serum (FBS; Gibco, ThermoFisher Scientific, USA). The cells were incubated in a $37^{\circ} \mathrm{C}, 5 \% \mathrm{CO}_{2}$ atmosphere. The cells were transfected with siRNA-Angptl7 (si-Angptl7) and siRNA control (si-NC) in HUVEC. The sequences of siRNA-1 targeting ANGPTL7 were sense: 1 5'-GCACAAGACACCAGCACA Gtt-3' and anti-sense 5'-CUGUGCUGGUGUCUUGUG Ctt-3'. The siRNAAngptl7 and negative control were purchased from $\mathrm{Ge}$ nePharma (Shanghai, China). Transfection of si-Angptl7 and si-NC was performed using Lipofectamine 2000 (Invitrogen) according to manual's protocol.

\section{Cell counting kit-8 (CCK-8)}

To induce an adhesion and oxidative stress in HUVEC, cell viability of HUVEC was determined by CCK-8 assay kit (Glpbio Technology, China) according to the manufacturer's introductions. In brief, the cells were seeded at a concentration of $1 \times 10^{4}$ cells suspended in $100 \mu$ culture medium each well. After cells were attached to plate, they were treated with TNF- $\alpha(0,1,5,10,20,40,80 \mathrm{ng} / \mathrm{ml})$ and incubated for $48 \mathrm{~h}$. Subsequently, the absorbance data were obtained by Varioskan LUX Multimode Microplate Reader (Thermofisher Scientific, USA).

\section{Western blotting}

The Western blotting was performed to detect the protein levels according to previous investigation (Pan 2017). Angptl7 transfected and un-transfected HUVEC were treated with TNF- $\alpha(40 \mathrm{ng} / \mathrm{ml})$ for $48 \mathrm{~h}$ with a density of $8 \times 10^{5}$ cells/ well in 6-well plates. The following antibodies were used: Angptl7, eNOS, NF-kB, Nrf-2, HO-1, GAPDH, and HRPconjugated secondary antibodies. The immune-blotting was visualized using BioSpectrum Gel Imaging System (Bio-Rad, USA) and analyzed by Image J 1.8.0.

\section{$R T-P C R$}

Total RNA was extracted and purified using RiboPure ${ }^{\mathrm{TM}}$ RNA Purification Kit (Invitrogen; ThermoFisher Scientific). Subsequently, cDNA was synthesized from purified total RNA using SuperScript ${ }^{\mathrm{TM}}$ IV First-Strand Synthesis System (Invitrogen; ThermoFisher Scientific). Finally, SYBR ${ }^{\mathrm{TM}}$ Green PCR Master Mix (Applied Biosystems; ThermoFisher Scientific) was performed to detect gene expression. All assay kits were used in line with the manufacturer's instructions. QuantStudio 2 Real-Time PCR System (Applied Biosystems; ThermoFisher Scientific) was used to detect and analyze the expression levels of gene.

\section{Reactive oxygen species (ROS) production}

ROS was measured by ROS assay kit (Beyotime Biologic Technology, China) according to the manual's protocol. In brief, cells $\left(4 \times 10^{5}\right.$ cells/well) seeded in 6 -well plates were treated as described in section Western blotting. The cells were resuspended in a serum-free culture medium containing 2',7'-dichlorofluorescein diacetate (DCFH-DA) detection probe. The fluorescent intensity in different groups was detected using a flow cytometer (Becton-Dickinson, USA). 


\section{NO production}

Cells $\left(4 \times 10^{5}\right.$ cells/well) were treated as described in section Western blotting. The culture medium was collected and NO in different groups was quantified by the Griess method according to the manual's protocol (Beyotime Biologic Technology, China).

\section{The detection of inflammatory factors by ELISA}

Cells $\left(4 \times 10^{5}\right.$ cells/well) were treated as described in section Western blotting. Levels of IL-1 $\beta$ (ab100562, Abcam), IL-6 (ab178013, Abcam), Cox-2(DYC4198-2, R\&D systems) in culture medium were measured using commercial assay kit according to manual. The data were detected by Varioskan LUX Multimode Microplate Reader (Thermofisher Scientific, USA).

\section{Cell adhesion assay}

Cells were digested to cells suspension and diluted into proper concentration with medium. Cells suspension in TNF- $\alpha$-treated group was added with TNF- $\alpha$ in $10 \mathrm{ng} / \mathrm{ml}$. $5 \times 10^{6}$ cells were added in each well of a 12 -well plates. Cells were transfected with si-NC or si-Angptl7 and both treated with TNF- $\alpha$ (TNF- $\alpha+$ si-NC and TNF- $\alpha+$ si-Angptl7 group) to evaluate the effects of Angptl7 in TNF- $\alpha$-induced cells. These two groups were processed in the similar way like TNF- $\alpha$-treated group, but the cells were transfected with shRNA in advance. After $8 \mathrm{~h}$, cells were washed with PBS and stained with DAPI (ThermoFisher Scientific, USA). Image J 1.8.0 was performed to measure the adhesion cells.

\section{Statistical analysis}

Data were presented as mean \pm standard deviation (SD). Multiple comparisons were performed using one-way ANOVA analysis following with Turkey's test. Difference between groups was determined by Student's $t$-test. A $p$-value $<0.05$ was considered as a statistical difference.

\section{Results}

\section{TNF- $\alpha$ induced expression of Angptl7 in HUVEC}

TNF- $\alpha$ is usually highly expressed in atherosclerotic dysfunction and causes a variety of vascular diseases. More than $10 \mathrm{ng} / \mathrm{ml}$ of TNF- $\alpha$ resulted in toxicity for HUVEC, and $40 \mathrm{ng} / \mathrm{ml}$ of TNF- $\alpha$ led to approximately $50 \%$ cell death (Fig. 1). Since some effects of Angptl7 in atherosclerosis have been found in previous investigation, we detected the expression of Angptl7 in TNF- $\alpha$-induced HUVEC. The protein and
mRNA levels of Angptl7 were prominently reinforced in TNF- $\alpha$-induced HUVEC compared with the normal control (Fig. 2A and B). Then cells were transfected with Angptl7 shRNA and control shRNA, and all groups were induced by TNF-a. Angptl7 levels were drastically decreased in siAngptl7-1 group (Fig. 2C and D), thus it was chosen for the following experiment.

\section{TNF- $\alpha$-induced oxidative stress and inflammation were mediated by Angptl7}

TNF- $\alpha$ has been reported to induce HUVEC oxidative stress. To investigate the role of Angptl7 in TNF- $\alpha$-induced oxidative stress, we evaluated the levels of ROS, NO and eNOS. Results exhibited that the generation of ROS induced by TNF- $\alpha$ was significantly reduced by inhibition of Angptl7 in HUVEC (Fig. $3 \mathrm{~A})$. TNF-a-impaired production of NO was significantly reversed by inhibiting Angptl7 in HUVEC (Fig. 3B). Inhibition of Angptl7 abrogated the TNF-a-induced downregulation of eNOS, which catalyzed the production of NO (Fig. 3C). In addition, silencing Angptl7 diminished TNF- $\alpha$-induced expression of Cox-2, IL-1 $\beta$, and IL-6 (Fig. 3D-F).

\section{TNF- $\alpha$-induced cell adhesion was mediated by Angptl7}

Exogenous TNF-a significantly enhanced cell adhesion of HUVEC (Fig. 4) which is consistent with previous studies. However, cutting down the expression of Angptl7 dramatically reduced the adhesion cells (Fig. 4), indicating that Angptl7 might play a role in TNF- $\alpha$-induced cell adhesion.

\section{Effect of Angptl7 on NF- $\kappa B$, Nrf-2 signaling in HUVEC}

The expression levels of NF- $\kappa \mathrm{B}$ were prominently increased induced by TNF- $\alpha$, whereas Nrf-2 and HO-1

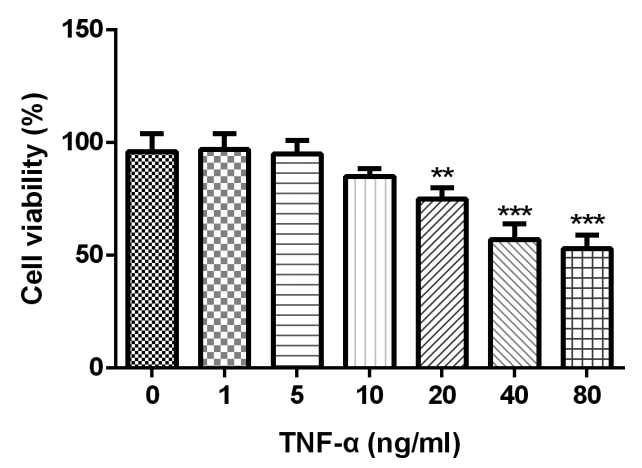

Figure 1. Cell viability of HUVEC treated with TNF- $\alpha$. Cells were treated with various concentrations of TNF- $\alpha(0,1,5,10,20,40$, $80 \mathrm{ng} / \mathrm{ml}$ ) for $24 \mathrm{~h}$. Cell viability was detected by CCK-8 analysis. Data were represented by mean $\pm \mathrm{SD} .{ }^{* *} p<0.01,{ }^{* * *} p<0.001 \mathrm{vs}$. $0 \mathrm{ng} / \mathrm{ml}$ TNF- $\alpha$. 
A
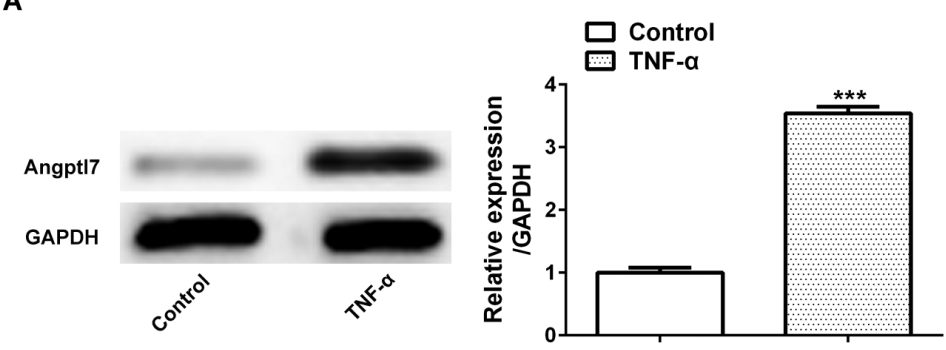

C
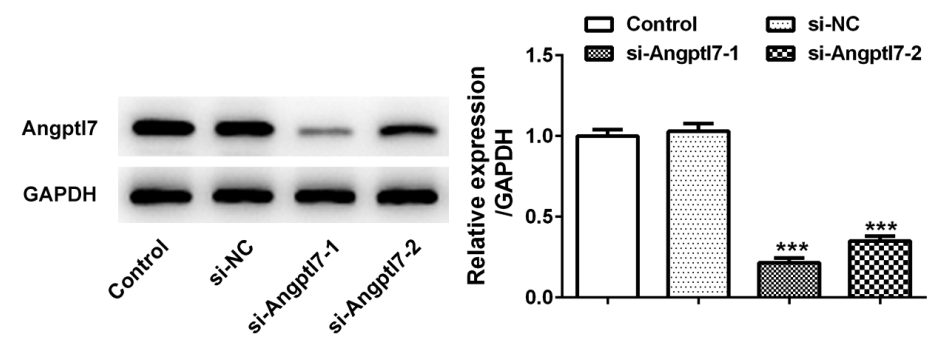

B

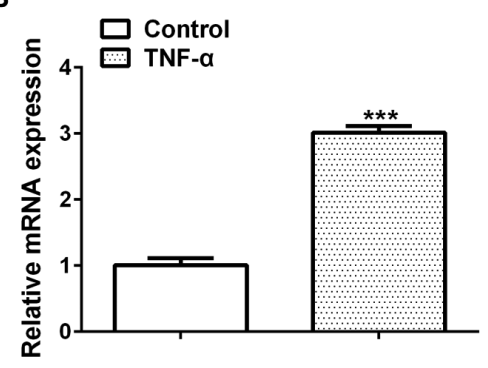

D

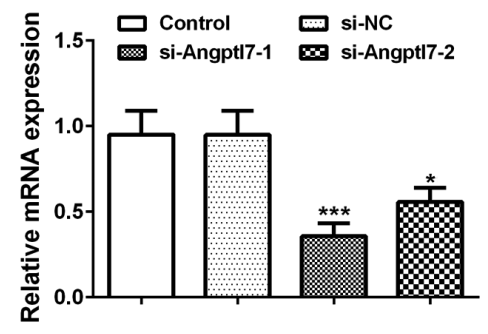

Figure 2. TNF- $\alpha$ induced expression levels of Angptl7 in HUVEC. The expression of Angptl7 (A and B) and the transfection efficacy of Angptl7 (C and D), both induced by TNF- $\alpha(40 \mathrm{ng} / \mathrm{ml}$ ), were detected by Western blotting (on the left) and mRNA (on the right). The two silenced sequences (si-Angptl7-1 and si-Angpt17-2) were respectively used to knockdown the Angptl7 expression and sequence 1 named si-Angptl7-1 was used in the following experiment. Data were represented by mean \pm SD. ${ }^{*} p<0.05,{ }^{* * *} p<$ 0.001 vs. Control.

were decreased in TNF- $\alpha$-induced HUVEC compared to the control (Fig. 5). Downregulation of Angptl-7 reversed the effects on TNF- $\alpha$-induced alteration of NF- $\kappa B, N r f-2$ and HO-1 (Fig. 5). Therefore, TNF- $\alpha$-induced activation of NF- $\kappa \mathrm{B}$ and inhibition of $\mathrm{Nrf}-2 / \mathrm{HO}-1$ may be mediated by Angptl7.
A

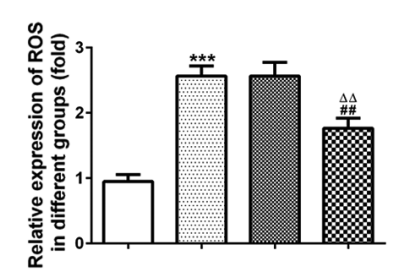

D

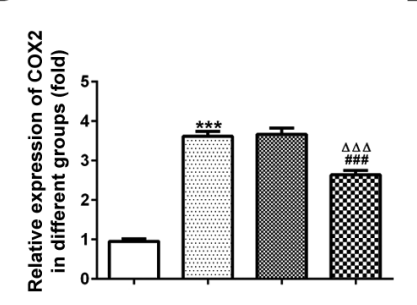

B

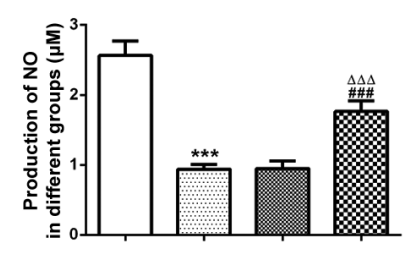

E

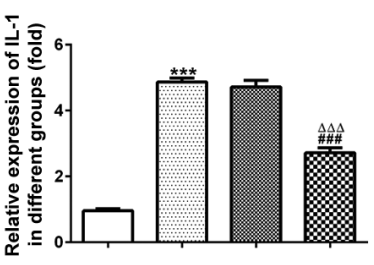

C
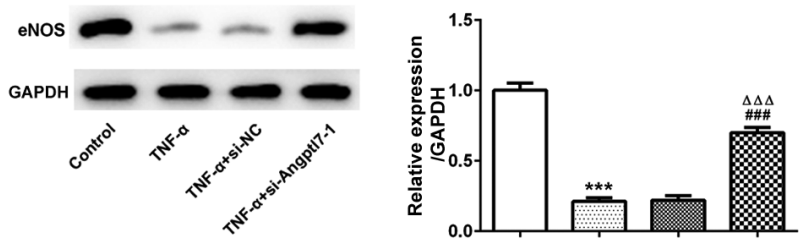

$\mathbf{F}$

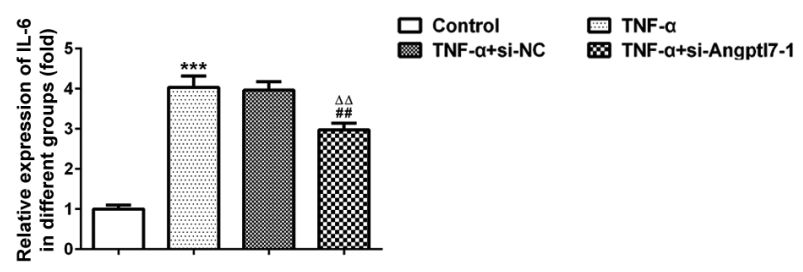

Figure 3. TNF- $\alpha$ induced oxidative stress and inflammation mediated by Angptl7 in HUVEC. ROS production (A), NO (B), Cox-2 (D), IL-1 $\beta$ (E) and IL-6 (F) levels were detected by ELISA analysis in different groups. C. The expression levels of eNOS was determined by Western blotting. TNF- $\alpha, 40 \mathrm{ng} / \mathrm{ml}$ for $24 \mathrm{~h}$. Data were represented by mean \pm SD. ${ }^{* *} p<0.001$ compared to control; ${ }^{\# \#} p<0.01$, ${ }^{\# \#} p<$ 0.001 vs. TNF- $\alpha ;{ }^{\Delta \Delta \Delta} p<0.001$ vs. TNF- $\alpha+$ si-NC. 


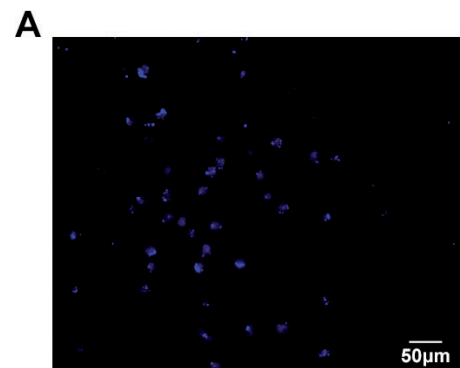

Control

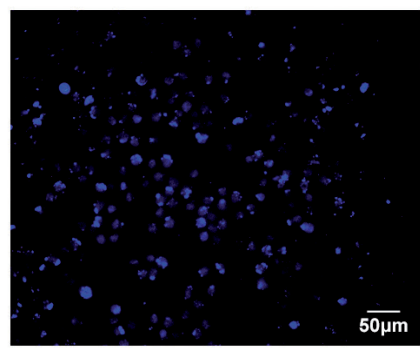

TNF-a+si-NC

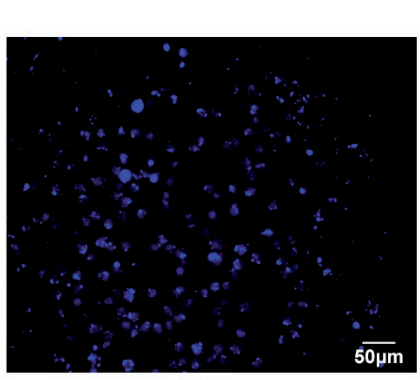

TNF- $\alpha$

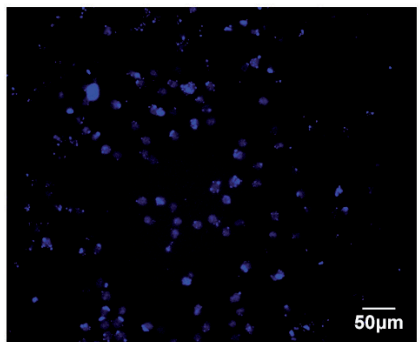

TNF- $\alpha+$ si-Angpt17-1

B
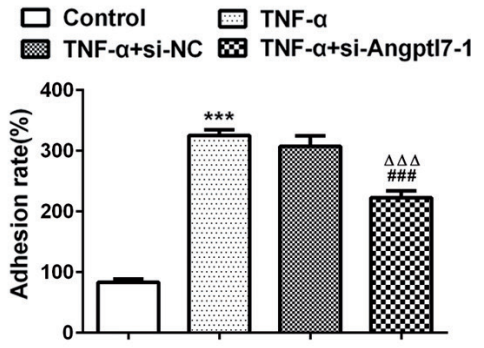

Figure 4. Angptl7 participates in TNF- $\alpha$-induced cell adhesion. Cells nuclei were stained with DAPI and attached cells were count by Image J. TNF- $\alpha, 40 \mathrm{ng} / \mathrm{ml}$ for $24 \mathrm{~h}$. Data were represented by mean $\pm \mathrm{SD}$. ${ }^{* *} p<$ 0.001 vs. control; ${ }^{\# \# \#} p<0.001$ vs. TNF- $\alpha ;{ }^{\Delta \Delta \Delta} p<0.001$ $v s$. TNF- $\alpha+$ si-NC.

\section{Discussion}

Absence of normal endothelial function is a critical risk in atherosclerosis. Inflammation is vital in the progression of atherosclerosis, and it usually leads to endothelial dysfunction (Dinh et al. 2014). Moreover, the inflammatory factor TNF- $\alpha$ has been found to induce extracellular matrix deposition on arterial walls, resulting in the increase of IL-1 $\beta$ and IL-6 (Tsutamoto et al. 2000; Zhou et al. 2018). Inflammation and dysregulation in endothelial and vascular smooth muscle cells play critical roles in plaque formation and rupture (Rai and Agrawal 2017). The salient discovery in the present study is that Angptl7 plays a role in the TNF- $\alpha$-induced endothelial dysfunction including oxidative stress, inflammation and adhesion.

A growing evidence indicates that selectively targeting oxidative stress can be an effective therapeutic modality for

A
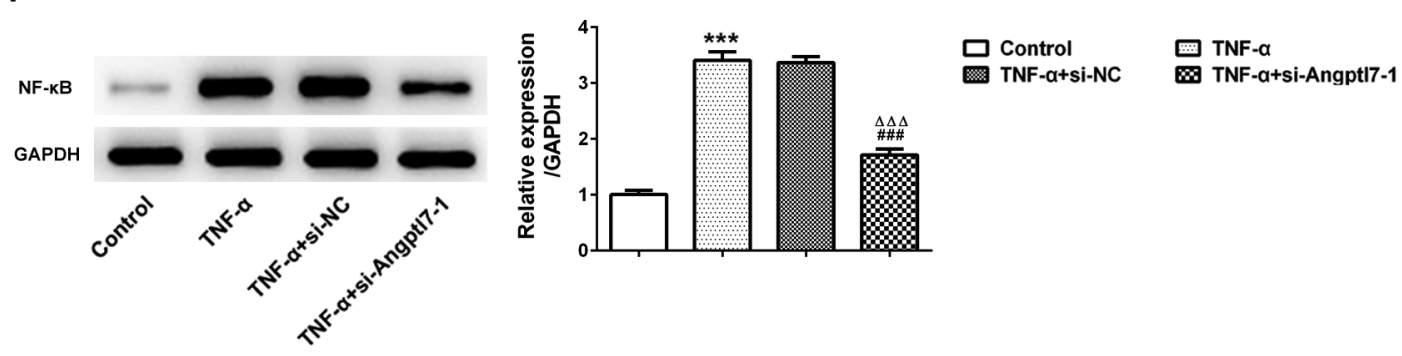

B
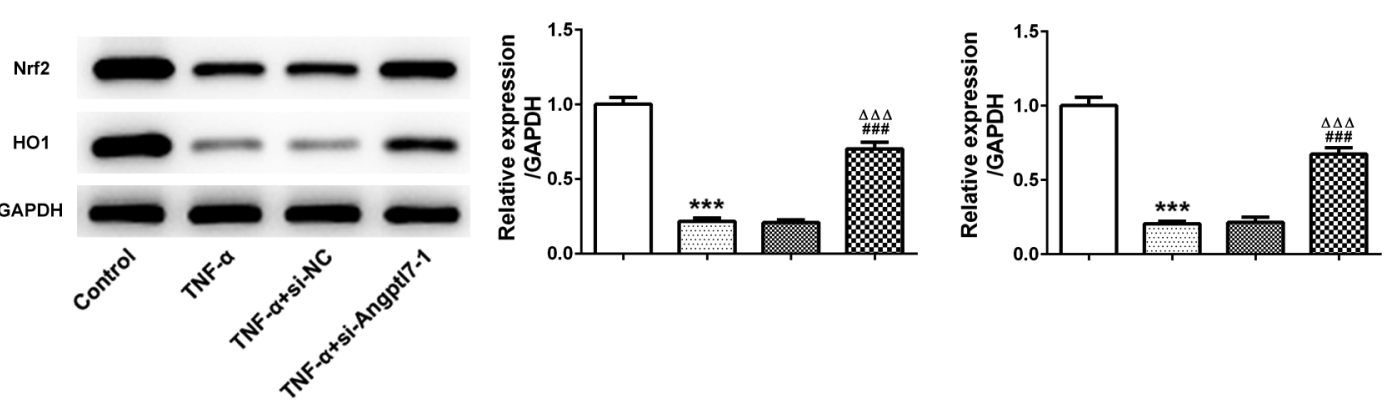

Figure 5. Angptl7 regulates TNF- $\alpha$-induced NF- $\kappa \mathrm{B}$ activation and Nrf-2/HO-1 inhibition. The expression of NF- $\kappa \mathrm{B}(\mathrm{A}), \mathrm{Nrf}-2$ and $\mathrm{HO}-1$ (B) was detected by Western blotting. TNF- $\alpha, 40 \mathrm{ng} / \mathrm{ml}$ for $24 \mathrm{~h}$. Data were represented by mean \pm SD. ${ }^{* * *} p<0.001 v s$. control; ${ }^{\# \#} p<$ $0.001 v s$. TNF- $\alpha ;{ }^{\Delta \Delta \Delta} p<0.001 v s$. TNF- $\alpha+\operatorname{si-NC}$. 
atherosclerosis (Kattoor et al. 2017). In the present study, Angptl7 significantly alleviated TNF- $\alpha$-induced ROS levels and promoted NO production, indicating that Angptl7 performed effective role in oxidative stress. Continuous release of NO in endothelium of blood vessels acts a solid part in cardiovascular disease, due to inhibiting vascular smooth muscle cell proliferation, reducing platelet activation and assembly, and abrogating atherosclerosis (Yang et al. 2015). Endothelial NO generation is catalyzed by eNOS and enzymatic cofactor tetrahydrobiopterin (Yu and Liu 2018). Therefore, Angptl7 might alleviate the catalytic effects of eNOS to reduce NO generation.

Angptl7 promotes inflammation in macrophages through p38 MAPK signaling pathway, and injections of TNF- $\alpha$ promotes the expression of Angptl7 in mouse eyes (Qian et al. 2016). In the current study, Angptl7 was upregulated in TNF- $\alpha$-induced HUVEC. Furthermore, inhibition of Angptl7 reduced the TNF- $\alpha$-induced generation of IL- $1 \beta$, IL-6 and Cox-2. Downregulation of NF- $\kappa B$ inhibits inflammation to exert atheroprotective effects (Shen et al. 2019). Reduction of inflammation and adhesion in endothelial might contribute to reduction of atherosclerosis (Tsujikawa et al. 2019). The current study revealed that inhibition of Angptl7 could decrease the expression of NF- $\mathrm{kB}$. Endothelial regulates leukocyte recruitment to exert pro-inflammatory effects, including promoting the expression of ICAM-1, IL-6, IL-8, and Céx-2 (Kuldo et al. 2005). HUVEC adhesion to monocytes has been indicated as an initiator of inflammatory vascular diseases including atherosclerosis (Xu et al. 2019). Our study preliminarily showed that inhibition of Angptl7 could reduce cell adhesion of HUVEC. However, more evidence is still needed for further study on the adhesion of HUVEC in atherosclerosis.

The Nrf-2/HO-1 signaling pathway is one of the key mechanisms in cellular anti-oxidative effects. Nrf-2 directly regulates ROS mediated by antioxidant defense systems through various mechanisms including induction of stress response proteins (HO-1) (Ma 2013). The present study showed that inhibition of Angptl7 reactivated the Nrf/HO-1 signaling pathway, indicating that it might mediate Angptl7 triggered effects in HUVEC. In addition, activation of Nrf-2 plays a role in the protection of atherosclerosis (Kim et al. 2012). However, further investigations still require deep exploration.

\section{Conclusions}

Our results firstly showed the role of Angptl7 in TNF- $\alpha$ induced inflammatory factors release, disorder production of $\mathrm{NO}$ and ROS and adhesion. Downregulation of Angptl7 activated Nrf-1/HO-1 and attenuated NF- $\mathrm{BB}$ signaling pathway. Manifest evidence indicated the close correla- tion between atherosclerosis and endothelial dysfunction (Gimbrone and Garcia-Cardena 2016). The current data proved the potential of Angptl7 in endothelial dysfunction. Nevertheless, further studies are needed to investigate the mechanism of it.

\section{Acknowledgment. Not applicable.}

Foundation. Lanzhou Talent Project for Innovation and Entrepreneurship (2015-RC-12).

\section{References}

Bar A, Targosz-Korecka M, Suraj J, Proniewski B, Jasztal A, Marczyk B, Sternak M, Przybylo M, Kurpinska A, Walczak M, et al. (2019): Degradation of glycocalyx and multiple manifestations of endothelial dysfunction coincide in the early phase of endothelial dysfunction before atherosclerotic plaque development in apolipoprotein E/low-density lipoprotein receptordeficient mice. J. Am. Heart Assoc. 8, e011171 https://doi.org/10.1161/JAHA.118.011171

Bhaskar S, Sudhakaran PR, Helen A (2016): Quercetin attenuates atherosclerotic inflammation and adhesion molecule expression by modulating TLR-NF-kappaB signaling pathway. Cell Immunol. 310, 131-140 https://doi.org/10.1016/j.cellimm.2016.08.011

Dinh QN, Drummond GR, Sobey CG, Chrissobolis S (2014): Roles of inflammation, oxidative stress, and vascular dysfunction in hypertension. Biomed. Res. Int. 2014, 406960 https://doi.org/10.1155/2014/406960

Ende G, Poitz DM, Wiedemann E, Augstein A, Friedrichs J, Giebe S, Weinert S, Werner C, Strasser RH, Jellinghaus S (2014): TNF-alpha-mediated adhesion of monocytes to endothelial cells-The role of ephrinA1. J. Mol. Cell. Cardiol. 77, 125-135 https://doi.org/10.1016/j.yjmcc.2014.10.010

Forstermann U, Xia N, Li H (2017): Roles of vascular oxidative stress and nitric oxide in the pathogenesis of atherosclerosis. Circ. Res. 120, 713-735 https://doi.org/10.1161/CIRCRESAHA.116.309326

Gimbrone MA, Jr., Garcia-Cardena G (2016): Endothelial cell dysfunction and the pathobiology of atherosclerosis. Circ. Res. 118, 620-636 https://doi.org/10.1161/CIRCRESAHA.115.306301

Kapoor R, Sirohi VK, Gupta K, Dwivedi A (2019): Naringenin ameliorates progression of endometriosis by modulating Nrf-2/Keap1/HO1 axis and inducing apoptosis in rats. J. Nutr. Biochem. 70, 215-226 https://doi.org/10.1016/j.jnutbio.2019.05.003

Kattoor AJ, Pothineni NVK, Palagiri D, Mehta JL (2017): Oxidative stress in atherosclerosis. Curr. Atheroscler. Rep. 19, 42 https://doi.org/10.1007/s11883-017-0678-6

Kim M, Kim S, Lim JH, Lee C, Choi HC, Woo CH (2012): Laminar flow activation of ERK5 protein in vascular endothelium leads to atheroprotective effect via NF-E2-related factor 2 (Nrf-2) activation. J. Biol. Chem. 287, 40722-40731 
https://doi.org/10.1074/jbc.M112.381509

Kuldo JM, Westra J, Asgeirsdottir SA, Kok RJ, Oosterhuis K, Rots MG, Schouten JP, Limburg PC, Molema G (2005): Differential effects of NF-\{kappa\}B and p38 MAPK inhibitors and combinations thereof on TNF-\{alpha\}- and IL-1\{beta\}-induced proinflammatory status of endothelial cells in vitro. Am. J. Physiol. Cell. Physiol. 289, C1229-1239

https://doi.org/10.1152/ajpcell.00620.2004

Li X, Li X, Lin J, Sun X, Ding Q (2019): Exosomes derived from low-intensity pulsed ultrasound-treated dendritic cells suppress tumor necrosis factor-induced endothelial inflammation. J. Ultrasound Med. 38, 2081-2091 https://doi.org/10.1002/jum.14898

Ma Q (2013): Role of nrf2 in oxidative stress and toxicity. Annu. Rev. Pharmacol. Toxicol. 53, 401-426 https://doi.org/10.1146/annurev-pharmtox-011112-140320

Migrino RQ, Davies HA, Truran S, Karamanova N, Franco DA, Beach TG, Serrano GE, Truong D, Nikkhah M, Madine J (2017): Amyloidogenic medin induces endothelial dysfunction and vascular inflammation through the receptor for advanced glycation endproducts. Cardiovasc. Res. 113, 1389-1402 https://doi.org/10.1093/cvr/cvx135

Napoleone E, Di Santo A, Lorenzet R (1997): Monocytes upregulate endothelial cell expression of tissue factor: a role for cell-cell contact and cross-talk. Blood 89, 541-549 https://doi.org/10.1182/blood.V89.2.541

Onat D, Brillon D, Colombo PC, Schmidt AM (2011): Human vascular endothelial cells: a model system for studying vascular inflammation in diabetes and atherosclerosis. Curr. Diab. Rep. 11, 193-202 https://doi.org/10.1007/s11892-011-0182-2

Pan JX (2017): LncRNA H19 promotes atherosclerosis by regulating MAPK and NF-kB signaling pathway. Eur. Rev. Med. Pharmacol. Sci. 21, 322-328

Parri M, Pietrovito L, Grandi A, Campagnoli S, De Camilli E, Bianchini F, Marchio S, Bussolino F, Jin B, Sarmientos P, et al. (2014): Angiopoietin-like 7, a novel pro-angiogenetic factor over-expressed in cancer. Angiogenesis 17, 881-896 https://doi.org/10.1007/s10456-014-9435-4

Qian T, Wang K, Cui J, He Y, Yang Z (2016): Angiopoietin-like protein 7 promotes an inflammatory phenotype in RAW264.7 macrophages through the P38 MAPK signaling pathway. Inflammation 39, 974-985 https://doi.org/10.1007/s10753-016-0324-4

Rai V, Agrawal DK (2017): The role of damage- and pathogenassociated molecular patterns in inflammation-mediated vulnerability of atherosclerotic plaques. Can. J. Physiol. Pharmacol. 95, 1245-1253 https://doi.org/10.1139/cjpp-2016-0664

Schulze-Osthoff K, Beyaert R, Vandevoorde V, Haegeman G, Fiers W (1993): Depletion of the mitochondrial electron transport abrogates the cytotoxic and gene-inductive effects of TNF. EMBO J. 12, 3095-3104 https://doi.org/10.1002/j.1460-2075.1993.tb05978.x

Shan Y, Jiang B, Yu J, Wang J, Wang X, Li H, Wang C, Chen J, Sun J (2019): Protective effect of schisandra chinensis polysaccharides against the immunological liver injury in mice based on
Nrf-2/ARE and TLR4/NF-kappaB signaling pathway. J. Med. Food 22, 885-895 https://doi.org/10.1089/jmf.2018.4377

Shen W, Anwaier G, Cao Y, Lian G, Chen C, Liu S, Tuerdi N, Qi R (2019): Atheroprotective mechanisms of tilianin by inhibiting inflammation through down-regulating NF-kappaB pathway and foam cells formation. Front. Physiol. 10, 825 https://doi.org/10.3389/fphys.2019.00825

Tsujikawa LM, Fu L, Das S, Halliday C, Rakai BD, Stotz SC, Sarsons CD, Gilham D, Daze E, Wasiak S, et al. (2019): Apabetalone (RVX-208) reduces vascular inflammation in vitro and in CVD patients by a BET-dependent epigenetic mechanism. Clin. Epigenetics 11, 102

https://doi.org/10.1186/s13148-019-0696-Z

Tsutamoto T, Wada A, Maeda K, Mabuchi N, Hayashi M, Tsutsui T, Ohnishi M, Sawaki M, Fujii M, Matsumoto T, Kinoshita M (2000): Angiotensin II type 1 receptor antagonist decreases plasma levels of tumor necrosis factor alpha, interleukin-6 and soluble adhesion molecules in patients with chronic heart failure. J. Am. Coll. Cardiol. 35, 714-721 https://doi.org/10.1016/S0735-1097(99)00594-X

Virmani R, Kolodgie FD, Burke AP, Farb A, Schwartz SM (2000): Lessons from sudden coronary death: a comprehensive morphological classification scheme for atherosclerotic lesions. Arterioscler. Thromb. Vasc. Biol. 20, 1262-1275 https://doi.org/10.1161/01.ATV.20.5.1262

Xu Y, Huang D, Lu S, Zhang Y, Long M (2019): Mechanical features of endothelium regulate cell adhesive molecule-induced calcium response in neutrophils. APL Bioeng. 3, 016104 https://doi.org/10.1063/1.5045115

Yang B, Yin C, Zhou Y, Wang Q, Jiang Y, Bai Y, Qian H, Xing G, Wang S, Li F, et al. (2019): Curcumin protects against methylmercury-induced cytotoxicity in primary rat astrocytes by activating the Nrf-2/ARE pathway independently of PKCdelta. Toxicology 425, 152248 https://doi.org/10.1016/j.tox.2019.152248

Yang Z, Yang Y, Xiong K, Li X, Qi P, Tu Q, Jing F, Weng Y, Wang J, Huang N (2015): Nitric oxide producing coating mimicking endothelium function for multifunctional vascular stents. Biomaterials 63, 80-92 https://doi.org/10.1016/j.biomaterials.2015.06.016

Ye F, He J, Wu X, Xie J, Chen H, Tang X, Lai Z, Huang R, Huang $J$ (2019): The regulatory mechanisms of Yulangsan MHBFC reversing cardiac remodeling in rats based on eNOS-NO signaling pathway. Biomed. Pharmacother. 117, 109141 https://doi.org/10.1016/j.biopha.2019.109141

Yu L, Liu H (2018): Perillaldehyde prevents the formations of atherosclerotic plaques through recoupling endothelial nitric oxide synthase. J. Cell. Biochem. 119, 10204-10215 https://doi.org/10.1002/jcb.27362

Zhao Y, Liu K, Yin D, Lin Z (2019): Angiopoietin-like 7 contributes to Angiotensin II-induced proliferation, inflammation and apoptosis in vascular smooth muscle cells. Pharmacology 104, 226-234 https://doi.org/10.1159/000501296

Zhou P, Xie W, Luo Y, Lu S, Dai Z, Wang R, Sun G, Sun X (2018): Protective effects of total saponins of Aralia elata (Miq.) on endothelial cell injury induced by TNF-alpha via modulation 
of the PI3K/Akt and NF-kappaB signalling pathways. Int. J. Mol. Sci. 20, e36

https://doi.org/10.3390/ijms20010036

Zhu Y, Zhang Y, Huang X, Xie Y, Qu Y, Long H, Gu N, Jiang W (2019): Z-Ligustilide protects vascular endothelial cells from oxidative stress and rescues high fat diet-induced atheroscle- rosis by activating multiple Nrf- 2 downstream genes. Atherosclerosis $\mathbf{2 8 4}, 110-120$

https://doi.org/10.1016/j.atherosclerosis.2019.02.010

Received: August 5, 2019

Final version accepted: December 15, 2019 